\title{
Negotiating Hinduism In EAST AFRICA, 1860-1960
}

\section{Transforming Cultures eJournal, \\ Vol. 3 No 2, November 2008 http://epress.lib.uts.edu.au/journals/TfC}

\section{Gijsbert Oonk ${ }^{1}$}

Erasmus University Rotterdam, Netherlands

\begin{abstract}
This paper describes how Hindus in East Africa developed from 'South Asians in Africa' to 'Asian Africans' between 1880-1960. It shows how the Hindu community in East Africa realised their own geographical spaces and areas of interaction. The various cultural encounters of Hindus traders and businessmen with African, Arab and European communities may have been economically profitable, but they harmed cultural pillars of Hindu identity, like notions of caste, purity, food habits and marriage patterns. Obviously, this was not a harmonious process, but one with conflicts in which painful decisions had to be made and legitimised. For others, however, it was an opportunity to free themselves from the burden of religious patronage. The research is based on the history of more than twenty Hindu Lohana families who have lived in East Africa for three generations or more.
\end{abstract}

Hindus and Hinduism outside India represent a divergent diaspora. It is argued that Hindus in diaspora tend to reproduce religion, caste, sectarian and linguistic/regional traditions, albeit somewhat eroded according to local circumstances. ${ }^{2}$ Although processes of cultural change, assimilation and integration may take place within a 'global continuum' of relations, they only gain their significance in concrete historical contexts and inter-personal relations. ${ }^{3}$ This process of stretching and closing preferences of identity of minorities in an often hostile environment is frequently described as the outcome of a long-term process written from above, i.e. based on official colonial and institutional sources. Very little is known about the process itself, especially from sources within the community. This is particularly true for Hindus in East Africa where

\footnotetext{
${ }^{1}$ Gijsbert Oonk is Associate Professor in Non-Western History at the Erasmus University in Rotterdam. His most recent publication, an edited collection on the South Asian diaspora, is reviewed at the end of this issue.

${ }^{2}$ S. Vertovec, The Hindu Diaspora. Comparative Patterns (London: Routledge, 2000).

${ }^{3}$ L. Drummond, "The Cultural Continuum: A theory of intersystems," Man, 15 (1980): 352-374.
} 
we hardly find any sources written by the Hindu community itself, especially for the period before $1900 .{ }^{4}$ This paper is an attempt to describe areas of negotiating Hinduism from below.

In this paper I argue that Hindus in East Africa developed from 'South Asians in Africa' to 'Asian Africans' between 1880-1960.' The paper shows how the Hindu community in East Africa realised their own geographical spaces and areas of interaction. They had to sidestep some of their habits and develop others. The various cultural encounters of Hindu traders and businessmen with African, Arab and European communities may have been economically profitable, but they harmed cultural pillars of Hindu identity, like notions of caste, purity, food habits and marriage patterns. ${ }^{6}$ Obviously, this was not a harmonious process, but one with conflicts in which painful decisions had to be made and legitimised. For others, however, it was an opportunity to free themselves from the burden of religious patronage. ${ }^{7}$

Hindu Lohanas in East Africa come from the rural districts of Cutch and Kathiawar (Gujarat, West India). They were traditionally labourers, masons, husbandmen, shopkeepers and traders. It is said that their history is related to that of one of the Kshatria (warrior) castes, which in ancient times was called Lavan. The plural form of this was Lavanam and, over a period of time, it changed first to Lavana and finally to Lohana. In the nineteenth century, many turned to weaving and textile trading. Those in Kathiawar were especially well established as maritime traders and many were doing

\footnotetext{
${ }^{4}$ Unfortunately there are no sources of Hindu traders and travellers from that period left. The travelogue edited by C. Salvadori contains the histories of a Parsi and a Muslim Indian. C. Salvadori, Two Indian Travellers: East Africa 1902-1905, (Mombasa: Friends of Fort Jesus, 1997). Mehta mentions some sources published in Gujarati, but they are also written by non-Hindus. M. Mehta, "Gujarati Business Communities in East African Diaspora. Major Historical Trends," Economic and Political Weekly, (May 19 2001) 1738-1747. In addition, before 1900 it is very difficult to make out the religious background of migrants from their names. It was only in the twentieth century that especially business magnates like Ali Mulla Jivanji [Bohra] and Nassar Virji [Khoja] and others revised the spellings of their names from Jivanji to Jeevanjee and from Virji to Veerjee, in order to emphasize their Muslim background. In fact they were converted Hindus. Mehta, ibid, 1739.

${ }^{5}$ See also, G. Oonk, "The Changing Culture of the Hindu Lohana Community," Contemporary South Asia 13, 1 (2004): 7-23. The theoretical assumptions are reproduced here. Some of the findings are reproduced and refined.

${ }^{6}$ The profitability of Asian businesses in East Africa is not self-evident. See, G. Oonk, 'South Asians in East Africa (1880-1920) with a particular focus on Zanzibar: Toward a Historical Explanation of Economic Success of a Middlemen Minority', African and Asian Studies 5 (1) 2006, 57-89.

${ }^{7}$ C. Salvadori, Through Open Doors. A view of Asian Cultures in Kenya, (Nairobi: Kenya Publications, 1983), 97-98.
} 
business in Oman. When the Sultan of Oman moved his headquarters from Musquat to Zanzibar (1832), Lohana traders quickly followed him and set up shops. From there they spread to the mainland from 1885 onwards. $^{8}$

This research is based on the history of more then twenty Hindu Lohana families who have lived in East Africa for three generations or more. The Lohana form the majority of Hindus in East Africa. In 1995, it was estimated that, of the 10,000 Hindus in Tanzania, 3,000 were Lohana Hindus. The remainder were Bhatias, Patels, Vanias, Brahmins and 'others', but none of these other Hindu jatis had more than 800 people each. In the same year, the number of South Asian Muslims was estimated at 26,000. ${ }^{9}$ The families I studied include more than 200 people, of whom 78 were interviewed from 1999 to 2003, including a year's fieldwork between July 2002 and July 2003. Information on the occupation, knowledge of languages and nationality is available for almost all family members. Some seven or eight key informants have been interviewed more than three or four times. In addition all kinds of informal meetings, dinner parties and celebrations of holidays have been attended. Some people were interviewed after 2003 as well, during revisits in 2006 and 2007.

In this paper I argue that South Asian culture changed as a result of three areas of cultural contact:

1) Interaction with Swahili culture and adaptation to a new geographical and cultural environment, including being a minority in East Africa and thus being more inclined to leave internal differences behind;

2) Interaction with the white colonial elite, and the growing importance of 'western education' for South Asians in East Africa and the significance of the European market;

\footnotetext{
${ }^{8}$ Salvadori, Ibid, 103-105. The focus on (Lohana and Bathia) Hindus is a consequence of my personal network of Asian businessmen. C. Voigt-Graf, Asian Communities in Tanzania (Hamburg, Institut für Afrika-kunde), 53. Hindu Bhatias have the longest history in East Africa. They are a Gujarati merchant community with a long tradition in Cutch and Bombay (West India). They were probably among the first Hindus to trade with Zanzibar, as Sir Kirk mentioned in 1874 a Bhatia house that was fifth in descent from the founder of the firm. More than any other Hindu community they are known for their respectability and orthodox reputation. They built one of the first large temples in Mombasa in 1904 and, until that time, they followed the custom of shaving their heads. Their major economic success in East Africa was related to their close ties with the various Arabic rulers who employed them as customs masters in the second half of the nineteenth century

${ }^{9}$ Voigt-Graf, Asian ibid, 53.
} 
3) The cultural - and in some periods economic - outlook of Asians in East Africa towards South Asia, the 'homeland', the 'pure and original culture', whether imagined or not.

However the question remains: How and why does culture change and in what direction? These questions refer to a long debate in historical anthropology concerning concepts like acculturation, assimilation, integration, syncretism and diffusion. ${ }^{10}$ More recently these concepts have been overshadowed with notions of subordination, in general a top-down process from the subordinated non- western culture towards a more 'western' culture. ${ }^{11}$ The debate on globalisation seems to praise the post-modern global interaction process in which cultures 'are more globalized, cosmopolitan and creolised or hybrid than ever.' ${ }^{12}$ While processes of creolisation [mixing of cultures] may take place within a global continuum of relations, ${ }^{13}$ they nonetheless attain their significance in concrete contexts of inter-personal relations.

As most studies of colonialism have tended either to condemn or to celebrate the perspective of the coloniser, little attention has been paid to the actual strategies of the colonised. ${ }^{14}$ No doubt, cultural interaction - like economic interaction - is an uneven process in which different groups have different ranges of choice. It is, however, very difficult to define the various layers of power. The most obvious point is that most colonised cultures had little control over the 'coloniser's culture' and were not always willing to reproduce a worldview that was alien to them.

\footnotetext{
${ }^{10}$ In 1935, Redfield, Linton and Herskovits published their standard work on acculturation, R. Redfield, R. Linton and M. Herskovits, 'Outline for the study of acculturation,' American Anthropologist, (38) 1935/36, 149-152; M.J. Herkovits, Acculturation. The Study of Cultural Contact, New York 1938. They distinguish three types of results of acculturation: (1) acceptance, i.e. adoption of a large part of the other culture without protest or adaptation; (2) adaptation, combining some 'own' cultural elements and some cultural elements of the 'other' culture, and (3) reaction, i.e re-accentuation of the 'own' culture as a reaction to cultural interaction. See Herkovits, 135-138.

11 'Acculturation: culture change due to contact between societies; most often used to refer to adaptation of subordinate tribal societies to domination by Western societies.' Keesing 1976, 507; 'In case of colonization and enslavement, however, acculturation is meant to erase the host culture to the benefit of the dominant.' Lewis 1997, 5.

${ }^{12}$ S. Vertovec, in R. Cohen,' Global Diaspora. An Introduction'. London 1997, 128. See also the well known article of U. Hannerz, 'The World in Creolisation', Africa 57 (4).

${ }^{13}$ Drummond 1980, Hannerz 1996; 67-68.

${ }^{14}$ Good exceptions are: A. Nandy, The Intimate Enemy, Oxford 1983 and Ranajit Guha's series of 'subaltern studies.
} 
In this article I argue that there is a need to study cultural change as a local, bottom-up process - local, in the sense of a well-defined geographical and historical area, and bottom-up in the sense that we choose to take the perspective of the agent, the one who changes, adapts, mixes, integrates or assimilates. By taking this perspective we may gather a view of how the 'range of choices' is defined by the actors of change themselves. This may provide us with insights into the economic and cultural agenda of individuals as well as of groups in a fast changing economic and cultural environment.

\section{Hindu Migration and the Emergence of a Trading Minority in East}

\section{Africa}

If we look at the map of the Indian Ocean it is not surprising that there is a long history of exchange of trades, ideas, crafts and human beings between West India, the Arab countries and East Africa. Direct trade between the continents was constrained by the rhythm of the monsoons. From November to March the beautiful dhows sailed from West India to East Africa, and from April to October the return journey was made. The trade in cotton textiles, ivory and spices was profitable, but dangerous. Many traders did not return home safely. The rough sea, pirates and various diseases claimed the lives of many traders and early adventurers. These early contacts between Indians and East Africans go back at least 2000 years. The first undisputed written evidence of these early contacts is the Periplus of the Erythraean Sea, written by a Greek pilot in the first century A.D. The first sizeable trading posts emerged along the East African Coast at this period. When Vasco da Gama arrived in Mozambique, Mombassa, and Lindi in 1497, he was surprised at the number of Arabs and Indians he found there. ${ }^{15}$

\footnotetext{
${ }^{15}$ See for this early period the notable works of M.N. Pearson, Port Cities and Intruders. The Swahili Coast, India, Portugal in the Early Modern Area, Baltimore and London, 1998; K.N. Chaudhury, Trade and Civilization in the Indian Ocean. An Economic History from the Rise of Islam to 1750, Cambridge 1985 and by the same author, Asia Before Europe. Economy and Civilization of the Indian Ocean from the Rise of Islam to 1750, Cambridge, 1990.
} 


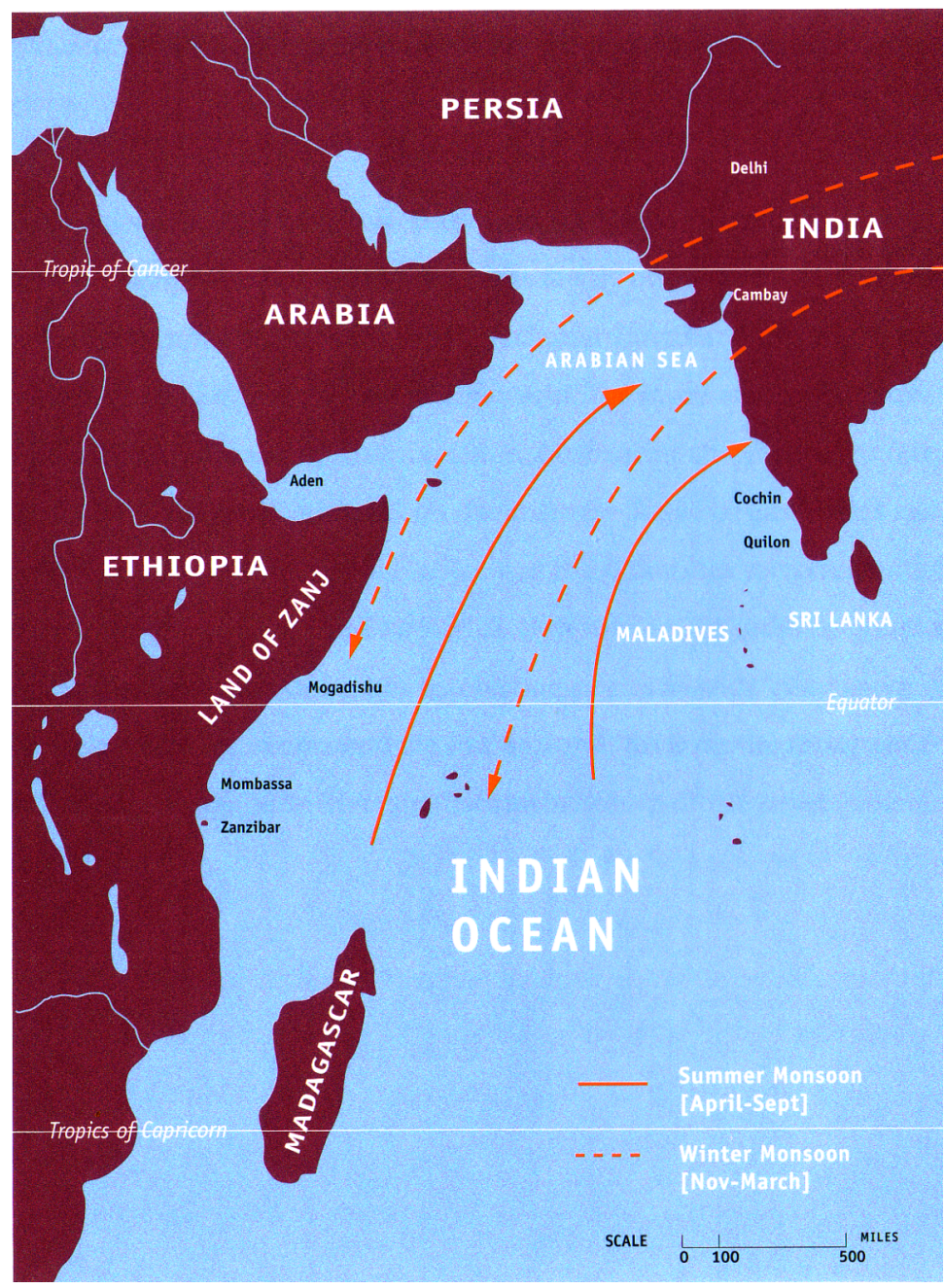

Reproduced from: G. Oonk, (2004) Asians in East Africa. Images, Histories \& Portraits, Arkel. See also: <www.asiansinafrica.com $>$

It was probably only in the late nineteenth century that a small community of Hindu Indian traders started to settle in Zanzibar and on the East African coast. These early Indian settlers are nowadays seen as the pioneers of many South Asian family business houses in East Africa, such as that of Keshavji Nandi who, at the age of ten, accompanied by his father to Zanzibar to look after some business opportunities. Most of these early migrants were asked to join the flourishing family businesses or to assist in the businesses of community members. Initially, they travelled back and forth to India, but slowly they settled in East Africa and invited their brothers and sisters, wives and children to join them.

The general migration history of Asian East Africans is well documented. Long before East Africa was 'discovered' by Europeans, Zanzibar and the East African coast were well-known trading destinations for Arabs and South Asians. These trading relations 
were strengthened during the establishment of the British Empire in East Africa. In the period between 1880 and 1920, the number of South Asians in East Africa grew from about 6,000 to 54,000. These included Hindus (among them well-known business families like Bhatias, Patels, Lohanas and Shahs), Muslims (especially Ithnasheries, Bohras and Ismailis), Sikhs, Goans and others. ${ }^{16}$

The various Asian business communities that arrived in the late nineteenth century developed far more intimate social and economic relationships with each other than they had done in India. These linkages resulted in new business habits, marriage policies and forms of capital accumulation. Their shared knowledge of the Gujarati language and their minority status (never more than $2 \%$ of the total population in East Africa, somewhat higher in the main trading ports) in a new society played an important role in this process. Despite the development of intimate socio-economic links, intercaste marriages and inter-religious marriages between Hindus and Muslims were still uncommon. $^{17}$

There is evidence that Hindus have been crossing the seas without compunction for many centuries, but the kind of ritual penances which had to be performed on their return are not always clear. The well-known Hindu text, The Code of Manu, explicitly states that sons who travel abroad are not allowed to take part in family rituals. Some suggest that such rules were used by Brahmins to keep merchant castes in their place. In some communities, such as that of the Gujarati Vanias of Porbandar during Gandhi's time, we know that some purifying rituals took place, but we lack information on other communities. ${ }^{18}$ One hypothesis that seems plausible, is that the generalised taboo on the voyage of women represented a kind of substitution. The fact that the woman of the household did not travel beyond the seas seems to have been sufficient to ensure the continuing purity of the household. In addition, a common home would be maintained

\footnotetext{
${ }^{16}$ R.G. Gregory, South Asians and East Africa: An Economic and Social History 1890 - 1980, (Boulder Colorado: Westview Press, 1993), pp.1-15.

17 See the introductions of: Robert G. Gregory, ibid; M. Mamdani, From Citizen to Refugee: Uganda Asians Come to Britain (London: Frances Pinter, 1973); R.R. Ramchandani, Uganda Asians. The End of an Enterprise: A Study of the Role of the People of Indian Origin in the Economic Development of Uganda and their Expulsion, 1894-1972 (Bombay: United Asia Publications, 1976).

${ }^{18}$ C. Markovits provides us with sketchy evidence on this, C. Markovits, The Global World of Indian Merchants 1750-1947. Traders of Sind from Bukhara to Panama (London: Cambridge University Press 2000) 27. Nevertheless, it seems plausible that these 'rites of passage' consisted of only 'light' rituals.
} 
in India in which family-worship, especially to honour the ancestors, would be performed and where family matters would be discussed and new ventures be planned. All revenues would be brought to the eldest in the family who initially stayed in India. The burden of crossing the sea may be light, nevertheless, questions remain about what happened when Hindus decided to take their wives and children to East Africa. ${ }^{19}$

\section{Being a Minority in a Hostile Environment}

Hindus made very different impressions on local people in the Indian Ocean world. Sometimes these impressions were warm and welcoming, but they could be harsh and rough as well. In this paragraph I introduce three very different impressions. The first impression is that of Somali people in North East Africa, as documented by the famous British explorer of East Africa, Richard F. Burton. The second impression comes from the well-known Arabic princess of Zanzibar and Oman, daughter of Sultan Said the Great, Sayyida Salme. The last impression is from the British traveller, W.G. Palgrave, who spent a year in Central and Eastern Arabia. He recalls the view of the Arabic elite in Oman and Muscat. These impressions illustrate the fact that Africans and the Arabs in East Africa tended to have a very negative image of Hindus in East Africa, whereas the ruling elites of Arabia generally harboured a far more positive account of them.

According to Burton, Somalis abused 'Asiatics' on all occasions for cowardice and a want of generosity. Burton recalls a piquant epigram.

Ask not thy want from Hindi:

Impossible to find liberality in the Hindi!

Had there been one liberal man in Al-Hind,

Allah had raised up a prophet in Al-Hind!"20

Although Burton is very outspoken about the character of the peoples he describes, he does not explain the differences in nature and personality, ${ }^{21}$ and, in this example, he

${ }^{19}$ C. Markovits, The Global World of Indian Merchants 1750-1947. Traders of Sind from Bukhara to Panama (London: Cambridge University Press 2000) 27; R. Nagar, "The South Asian Diaspora, 62-80; C. Salvadori, Through Open Doors. A view of Asian Cultures in Kenya (Nairobi: Kenyan Publishers, 1989), 96-97. It may not come as a surprise that descendents of Bhatias and Lohanas who have settled in East Africa do not remember any purifying rituals or religious barriers to travel over sea. They come from families which, eventually, have side-stepped these rituals, if they carried them at all.

${ }^{20}$ Richard F. Burton, First Footsteps in East Africa or, An Exploration of Harar, (New York: Dover Publications 1987 [1856]) 77.

21 Burton writes about Somalis: 'Somali people were very peculiar in mind and body. They had a susceptible character and were uncommonly hard to please. They disliked Arabs, Turks and Franks and they despised all Asiatics'. Ibid. 
provides no explanation for the negative image of Asiatics that Somalis evoke in their song. $^{22}$

We may find some more clues in the reference of Sayyida Salme, who recalls from her childhood how the end of Ramadan was celebrated in Zanzibar. Bullocks and other animals were slaughtered in the yards of many Arab houses and Hindus avoided these places for religious reasons. As they were strict vegetarians, they would be shocked by the image of killing animals, especially when this included the killing of holy cows. However, some Arabs provoked Hindus with these religious sentiments.

On such an evening, our slaughtering yard was changed into a lake of blood; for this reason all the banyans at Zanzibar, who are vegetarians, looked upon our feast with much horror, and took care not to come near any such places at this time. I have already spoken of these banyans as the principal traders and money-lenders in the town, and in the last capacity they are, beyond a doubt, the greatest cut-throats imaginable; they are bitterly hated on this account, and on occasions like these there is a splendid opportunity for their victims to take revenge upon them. Among the lower-class people it is a standing joke to entice the Banyans, who never allowed any chance of business to slip out of their grasp, under the pretence of some important order, into these blood streaming yards, which is the greatest insult that can be offered to the starworshippers, of whom it can be said, however, in spite of their low moral standing, that they adhere religiously to their code in being strict vegetarians. $^{23}$

In other words, Hindus were not very popular among the Arabs and Swahili. Salme provides us with clear-cut reasons for this: Hindus were well known money-lenders and traders who advanced money on landed security or credited trade goods. Many lower class Swahili and Arabs, however, felt that they were cheated by them, as they were seen as 'mugs with money', 'the greatest cut-throats imaginable', with a 'low moral standing'. 24

\footnotetext{
${ }^{22}$ In another book on Zanzibar we may get some information: Richard F. Burton, Zanzibar, vol II 1872, [Elibron Classics series 2003] on p. 407 he writes: 'Amongst natives money advanced on landed security or bottomry [sic] bear interest of 15-20 per cent per annum. As in Somaliland [italic mine], Banyans and large traders advance small ventures of goods, such as a bale of cloth, to the retail vendor who, during the season, barters it upon the coast and the interior for slaves and ivory, hide, copal, and grain. In these transactions the interest is enormous; consequently the merchant rolls in dollars, and the tradesman manages only to live. In other words, many Somalis were financially dependent on Hindus'. This financial dependency may evolve into bitter hatred, as in the case described by Sayyida Salme in the text.

${ }^{23}$ Emile Ruette, Princess Salme of Zanzibar and Oman, Memoires of an Arabian Princess, (Zanzibar: Gallery Publications, 1998 [1886]), pp. 133-134.

${ }^{24}$ Ibid. 134-136.
} 
The Arabic elite in Oman and Muscat, more particular Sultan Seyyid Said who believed that Hindus - and Indian merchants in general - were more enterprising than his own fellow subjects, countered these types of negative qualifications. In the words of the British traveller, W.G. Palgrave:

Saeed knew that, whatever might be the energy and enterprise of his own born subjects, their commercial transactions would never attain real importance except by the co-operation and under the lead of Indian merchants, and accordingly used every means in his power to allure the Banians of Cutch, Guzerat, and the Concan to Muscat, and by absolute toleration, special immunities, and constant patronage rendered the port a half-Hindoo colony. Nor had ever a government more useful, more steady-working, and more inoffensive protégés than the Banians proved themselves to Oman: interfering with no one, seeking nothing beyond their direct line of business, unobtrusive, courteous, and above all far more skilled in the mysteries of the ledger and the counter than ever Arab was or will be, they made the good fortune of Muscat and were its favorable genius. ${ }^{25}$

When Seyyid Said moved his capital from Oman to Zanzibar in 1832, he brought with him Indian traders from the Persian Gulf to run his commercial and financial affairs. ${ }^{26}$ In addition, he appointed the Hindu Bhatia, Jairam Sewji, as chief customs collectors in Zanzibar who served - with the exception of some brief periods - for almost 70 years in this position. This firm helped recruit hundreds of other Bhatias from India and set them up in business within the Zanzibar commercial empire. Besides acting frequently as customs collectors along the coast, Bhatias were also moneylenders and traders. ${ }^{27}$ As noted by Burton, most customs collectors along the East African coast were Hindu Bhatias:

Ladha Dama [sic] farms the customs at Zanzibar, at Pemba Island his nephew Pisu has the same charge: Mombasah [sic] is in the hands of

\footnotetext{
${ }^{25}$ W.G. Palgrave, Narrative of a year's Journey through Central and Eastern Arabia, London 1865, ii. 369-70.

${ }^{26}$ Sheriff, The Rise of a Commercial Empire: An Aspect of the Economic History of Zanzibar, 1770-1873. $\mathrm{Ph} . \mathrm{D}$. thesis, University of London, 1971, 348-49. He subsequently encouraged migrants from India through a variety of incentives including guarantees of religious tolerance, a minimum of $5 \%$ duty on imports and removal of restrictions on Indian land ownership. The earlier policy of opposing Indians as foreign traders was reversed and they were granted equal privileges with Arab traders, including permission to trade on the Mrima Coast. This area, stretching from Tangata to Kilwa, became an economic reserve under the control of the Sultan of Zanzibar. By the 1840s Indians were also allowed to acquire property and own clove plantations on Zanzibar.

27 Frere termed Bhatias as 'probably the most important by wealth and influence', Colonial Office (hereafter CO), Memo by Sir Bartle Frere, Correspondence 1856, p100.
} 
Lahmidas, and some 40 of his co-religionists; Pangani is directed by Trikandas and contains twenty Bhatias, including those of Mbweni; even the pauper Sa'adani had its Banyan; Ramji, an active and intelligent trader, presides at Bagamoyo, and the customs of Kilwa are collected by Kishnidas. I need hardly say that almost all of them are connected by blood as well as trade. ${ }^{28}$

But the Bhatias' fortunes were very closely tied to the Sultan. In 1879, the new Sultan, Sayyid Bargash, became dissatisfied with Sewji's firm and, for several years, gave control of the customs to an Ismaili, Tharia Topan. After the partition, in 1890, when the British and Germans seized control over the customs, the Bhatias' economic power declined and the proportion of Bhatias compared with the other communities decreased.

These sources show, on the one hand, the economic importance of the Hindu community for the Arab rulers in Zanzibar and the Coastal areas. ${ }^{29}$ The Hindus were welcomed by rulers, like Seyyid Said, who favoured and pampered them with all kinds of small and bigger gestures, like tax reductions and government protection. However, they had to pay a price. The farming of the customs in Zanzibar amounted to more than $\$ 100,000$ in the $1820 \mathrm{~s}$, and more than $\$ 200,000$ in the $1850 \mathrm{~s} .{ }^{30}$ On the other hand, Hindus were not very popular among the local Arabs and Swahili. Some of the Swahilis and lower class Arabs were financially dependent on Hindus. This financial dependency, could lead to bitter hatred, as in the cases described by Sayyida Salme.

This fits in a general framework where the African society is seen as a tripartite society, where the European minority was morally, politically and economically superior to the South Asian middlemen community and the African majority of subsistence farmers. These views of Asians or Indians were at least in part constructed by the differential ways in which they were incorporated into African society under colonialism. These

\footnotetext{
${ }^{28}$ Burton, Zanzibar 1, 328-329

${ }^{29}$ See also the example in the second part of this paper of Sultan Seyyid Bargash who in the early $1880 \mathrm{~s}$ encouraged Hindu women to settle in Zanzibar.

${ }^{30}$ Zanzibar Agency Administration Report to Secretary of State 1879, PRO/FO 84/1399, 119. Jairam Sewji's income was derived from the fact that all the exports must pass through the Customs House where his labourers transported the trade goods and he charged for this labour. Moreover, his position as the financial advisor to the Sultan helped him further to consolidate his business in Zanzibar. The rapid commercial growth at Zanzibar is also reflected in the rental increase in the customs farming. The farming of the customs in Zanzibar is well described by Abdul Waheed Naseem in his unpublished Ph.D., Nature and the Extent of the Indian Enterprise Along the East African Coast And Subsequently in the Development of Kenya 1840-1905. Submitted at St. John's University New York 1975, 38-51.
} 
constructions were inherent to the British tripartite system in East Africa that drew on these racialisations. ${ }^{31}$

Thus, the general impression from the sources, however poor, cited above is that Hindus in East Africa were welcomed by the rulers and elite in Zanzibar, but that they were disliked by other Arabs and Swahilis. One of the major consequences of this may be that they initially tended less to settle in East Africa. Hindus in East Africa were more 'birds of passage', whereas Indian Muslims tended to settle with their families earlier. In addition, those who (temporarily) settled in East Africa tended to live in the same areas, as it was almost unthinkable to share food with people from different backgrounds.

The British doctor, James Christie, observed in 1873 that:

Their food must be cooked by themselves, or by those of their own caste, and everything connected with their cooking and meals is according to their unvarying manners and customs. They thus fortunately escape the pollution of Negroes, and the cook of the house, one of their own class, is also water carrier; and as the cooking is of the simplest nature, the service of Negroes in the culinary department are not only dispensed, but are not allowed by custom. The water used must be drawn from their own wells, and by one of their own caste. No Banyan would touch, or allow himself to be touched by, water drawn by another save of his own caste. $^{32}$

Christie was interested in the customs related to hygiene of various communities in Zanzibar because of the spread of cholera. His observations on the cleanliness of Hindus above do not include the nature of the caste system which would make clear that Hindus at that time would not only not accept Swahili in their kitchen, but they would avoid accepting food from Europeans and any caste but their own, as well. Christie

\footnotetext{
${ }^{31}$ See W.G. Clarence-Smith, Indian and Arab Entrepreneurs in Eastern Africa, 1800-1914. In H.Bonin and $\mathrm{M}$ Cahen. (eds.) Négoce blanc en Afrique Noire : L'évolution du commerce à longue distance en Afrique Noire, du $18^{\mathrm{e}}$ au $20^{\mathrm{e}}$ siècles, 335-349. Paris: Société Française. Fore a more refined discussion see, G. Oonk: 'South Asians in East Africa (1880-1920) With a Particular Focus on Zanzibar. Towards a historical explanation of economic success of a middlemen minority', Journal of African and Asian Studies, 2006 (5) 1, 57-89 and G. Oonk, “'After shaking his hand, start counting your fingers". Trust and Images in Indian Business Networks, East Africa 1900-2000', Itinerario 200418 (3), 70-88.

32 James Christie, Cholera Epidemics in East Africa. An account of the several diffusions of the disease in that country from 1821 till 1872, with an outline of the geography, ethnology, and trade connections of the regions through which the epidemics passed (London: Macmillan, 1876), pp. 247-248.
} 
himself encountered this. Hindoos would not take any medicine in his office, i.e. they avoided his drinking water and took their own bottles. ${ }^{33}$

Because of these strict caste rules and notions of cleanliness, Hindus seem, more than other Indian, Arab and Swahili communities, to stick together. Palgrave referred to them as: 'interfering with no one, seeking nothing beyond their direct line of business. ${ }^{, 34}$ This is confirmed by early plans of cities in East Africa. If you look at old geographical maps of Zanzibar, Nairobi, Dar es Salaam and other places in East Africa there is always a 'Hindu quarter'. These quarters were not necessarily imposed by colonial politics, but may well be self-imposed, if only to avoid 'slaughtering of cows and goats' by Muslims in the backyard. This quarter, obviously, is a part of the larger 'Indian quarter'.

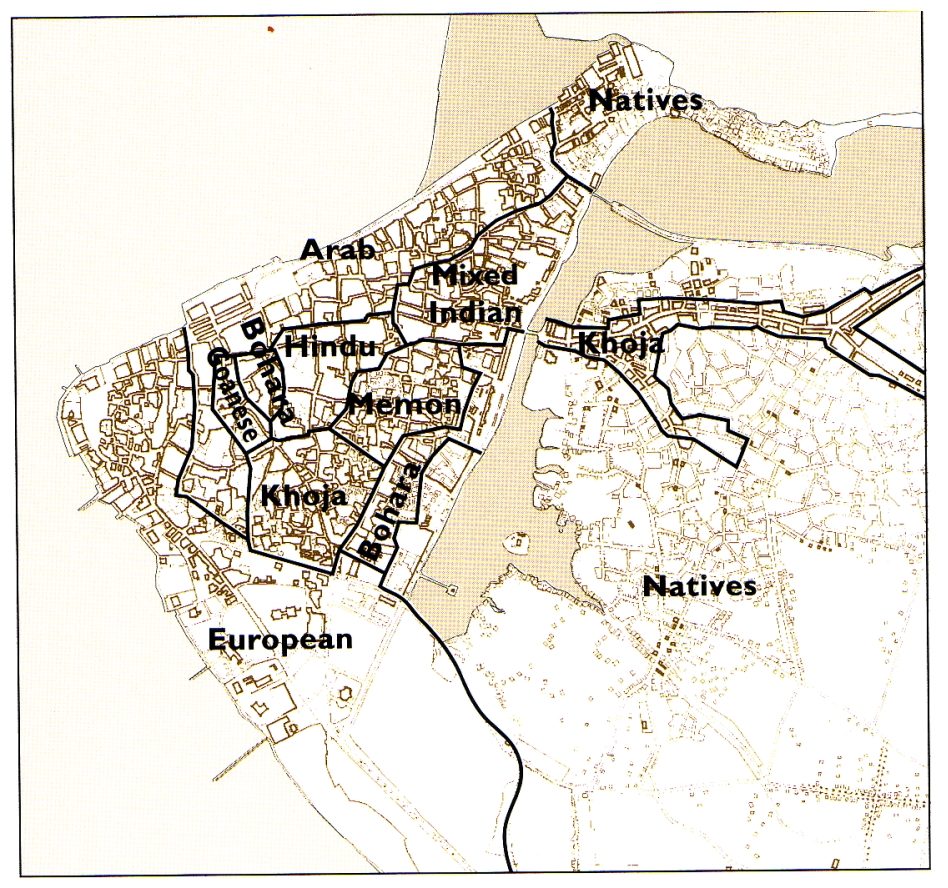

Map of Stonetown, Zanzibar, around 1923. It shows the racial distribution different communities. Reproduced from: A. Sheriff, Historical Zanzibar, Romance of the Ages, Zanzibar 1995.

In other words, Hindus shared various cultural traditions which made it more difficult for them to interact freely with others. This is not to say that they didn't have intercourse with other communities. Being businessmen, interaction with various communities was a part of the job. Yet even outside business activities, the total number

${ }^{33}$ Ibid 349. In addition he was struck by the inconsistency -in the eyes of Christie- of many Hindus who were delighted at having cows about their houses, so that where there was a central court it was filled with cows. Hindus were happy to sleep in small bedrooms next to the central court where they must have enjoyed the odour of cow-dung. Ibid 353.

${ }^{34}$ Palgrave, ibid. 
of South Asians in East Africa was so small that they had to interact with other communities more than they were used to back home. In Zanzibar, it appears that the leaders of the various Indian communities were concerned at the absence of any educational facilities for their children, and at a meeting convened by the British Consul and Agent, Charles Euan-Smith, they agreed to finance a school which they decided to place under the management of a committee elected from members of all Indian communities, both Muslim and Hindu. A sum of Rs.50,000 was subscribed at this meeting, and other donations quickly followed. When the school opened, there were two hundred pupils on the roll and a staff of teachers recruited in India. Gujurati and English were to be the languages taught. ${ }^{35}$

These initiatives were not exceptional. The Christian missionaries in East Africa had little interest in Indians. Nevertheless, Indians could not afford to remain uneducated. They were middlemen between the economy of the West and the Swahili farmers. Therefore, from the moment Gujaratis settled in East Africa, they took great interest in educating their children and started their own schools. During the colonial period most South Asians in East Africa went to so-called 'Indian schools', where they were taught to read and write their 'own' languages. Though many schools were intended for certain communities or initiated by religious institutions, others served a wide range of students of various backgrounds. ${ }^{36}$ Most of my respondents remembered having attended 'Indian schools' where Hindus and Muslims sat together. Many of these schools were (partly) financed by the well-off Indian business community and the colonial government. ${ }^{37}$

Despite these more intensive encounters with 'other Indians' in Zanzibar, there were hardly any intercultural marriages. Differences in religion, food habits and rituals

\footnotetext{
${ }^{35}$ FO 8430 July 1890, Euan-Smith to Lt. Salisbury; FO 84, 1 January 1891. In 1886 already, John Kirk had welcomed the initiative of Tharia Topan to open a school in Zanzibar: 'The rising Indian community there is undoubtedly far below the educational standard and business capacity of their fathers who came from Kutch...a knowledge of English is essential if the rising generation is to hold its own in keen competition with English, Americans, French and Germans. So great therefore, would be the benefit to be derived from good schools in Zanzibar for the rapidly increasing British Indian population that the scheme of Tharia Topan would be well worthwhile.” Kirk to Secretay of State, Zanzibar, May 1, 1886 F.O 84/1773 PRO London. The initiative from Topan was probably from 1883, however it was never implemented as he died in Bombay in 1885.

${ }^{36}$ Especially the followers of the Aga Khan, the Ismailis, who were quick to build their communally based Ismaili schools, which were nevertheless accessible to other Indians as well.

${ }^{37}$ For more on the education system, see G. Oonk, “'We lost our gift of expression”. Loss of the mother tongue among Indians in East Africa, 1880-2000', in G. Oonk (ed.), Debunking the Indian Diasporas. Empirical explorations and theoretical assumptions, Sage 2008.
} 
around death and birth may have prevented them from doing so. This was even more true regarding the encounters with Swahili, Europeans and Arabs. Being businessmen, they interacted with other cultures, but being Hindus they avoided any interaction. This apparent paradox is especially noteworthy in the case of Hindu traders and businessmen. They were not forced to trade with the Swahili coast but wanted to exploit the economic possibilities, even if this meant sidestepping their cultural background. This process of sidestepping eventually leads to the growing erosion of Hindu pillars of identity, like food habits and notions of caste and marriage preferences.

\section{Hindu Women and the Importance of Caste in East Africa}

As stated earlier, Hindu merchants rarely took their wives out of India, while Muslim merchants generally travelled with their families, especially to Muslim countries. The British doctor in Zanzibar, James Christie, wrote in 1876: 'They [the Hindus] never, even now, settle permanently, as it is not lawful, or according to their customs, for their women to cross the sea. ${ }^{38}$ Along the same lines, but more specifically about Hindu Bhatias, Richard Burton writes in his work on Zanzibar:

Not a Hindu woman is found upon the Island; all the banians leave their wives at home, and the consequences are certain peccadilloes, for which they must pay liberally. Arab women prefer them, because they have light complexions, they are generous in giving, and they do not indulge in four wives. Most of them, however, especially those settled on the coast, keep handsome slave girls, and as might be expected where illegitimates cannot be acknowledged, they labour under the imputation of habitual infanticide. ${ }^{39}$

Upper-caste Hindu men considered Africa to be 'alien' and 'unsafe' for women, and believed that women would be better cared for if they stayed behind in their own extended households in India. Owing to the economic and social uncertainty in East Africa, most Hindu women remained behind in India to look after their parents-in-law, children and property, and to supervise their children's education. In addition this helped to ensure that the man would come back. It may have been a way to legitimise travelling overseas.

\footnotetext{
38 James Christie, Cholera Epidemics in East Africa, 345. Contemporary sources on the position (and absence) of Hindu women in East Africa include: Burton, Zanzibar: City Island and Coast, 329-35; Pearce, Zanzibar, 257.

${ }^{39}$ Richard Burton, Zanzibar City, 329-335
} 
The Sultan of Zanzibar, Seyyid Bargash, must have been aware of this as he encouraged Hindus to bring their wives to his realm. Again, this is an example of elite Arabs encouraging Hindus to settle in Zanzibar, to overcome cultural barriers and to avoid interaction with the local, lower class people. In the early 1880 s he is reported to have sent his private vessel to welcome the first Hindu Bhatia woman in Zanzibar and gave her a reward of Shs 250/-. As a pledge of his good intentions, he promised to turn Zanzibar's Old Fort into a residence for the wives of merchants and offered to equip it with water pipes fitted with silver taps to ensure that Hindu women need never appear in public. This occurred precisely at the time the Hindu community in Gujarat revolted successfully against Brahmin priests and religious customs which were cramping their mercantile activities and making overseas commerce difficult. It was reasoned that they were justly pursuing their dharma by trading. ${ }^{40}$ The unmarried Hindu men generally went back to India to marry, and their wives stayed behind from the beginning, with the men making frequent trips back and forth. Otherwise, the women came to the East African coast for a few years, returning to India for childbirth. It was the practice of Hindu women to have the delivery of the babies -whenever possible- at their mothers' place. Often this was in Gujarat, India, where they generally remained for ten to twenty years, until their children had finished their education. ${ }^{41}$ The religious struggle for purity among Hindus contributed to all kinds of adjustments and rejections. As the marriage functions ought to be attended by Brahmins, who were still not allowed to travel overseas, the first generation got married in India. Some of the youngsters even went back for years to India in order to find a suitable spouse. Most marriages, however, were arranged, and it was just a matter of sailing the Indian Ocean, getting married and coming back.

Nevertheless, the fact that men traveled alone caused different problems. The food ought to be prepared by family members. Eating 'outside', 'taking food from others', was considered to be impure. This may have caused some 'delay' in the migration of Bhatias and Hindu Lohanas from Gujurat to East Africa. In other words, 'food constraints' were more easy to overcome if a small Hindu community was already settled in a certain area. This was also true for Hindu migrants who explored the

\footnotetext{
${ }^{40}$ Sheriff, The Rise of a Commercial Empire, 354.

${ }^{41}$ G. Oonk, 'The Changing Culture of the Hindu Lohana Community', Contemporary South Asia 13, 1 (2004): 7-23.
} 
upcountry trading routes towards what is nowadays Kenya and Uganda. Here again, Hindus were a little behind the Muslims in time and number.

There is very little evidence of Hindu movement to the interior before 1890. In general, the Indians remained in Zanzibar or the coastal port cities. They left the dangerous travel to the interior to the more experienced Arab and Swahili traders. ${ }^{42}$ Among the Indians, most probably the Muslims were first to discover the interior. The first Indian known to have settled upcountry was Musa Msuri, a Khoja from Surat. In 1825, he and his brother Sayyan set out on an expedition from Zanzibar and were probably the first non-Africans to reach Unyamwezi territory in western Tanzania, where they traded cloth and beads for ivory, turning a handsome profit. On the return Sayyam died. Musa, however, continued conducting caravans for another 30 years, reaching as far inland as Buganda in Uganda and Maragwe. ${ }^{43}$

In those days, there were three main routes to the interior. The first was opposite Zanzibar and with many side routes led to Tabora, then divided in three and passed on to the lakes. The second began on the southern Tanzanian coast, in towns like Kilwa, Lindi and Mkindani, and led to Lake Nyasa and then west. The third started in the north of Tanzania, in Pangani and Tanga, and went west to Mount Kilimanjaro and Lake Victoria. The Indian Khojas, Tharia Thopan [1823-?], Sewji Haji [1851-97], Allidina Visram [1851-1916] and Nasser Veerrjee [1865-1942], were among the principal financers of caravan traders in the late nineteenth century. Most of them managed their businesses from the coast, but they gathered first-hand information on the inland trade routes. Pioneers like Allidina Visram explored them himself. They established extensive upcountry $d u k a$ (small shops) networks throughout East Africa and invested in real estate, plantations, shipping and ginneries. At that time Hindus remained mainly active in the coastal cities, like Bagamoyo, Mombasa, Lindi, Kilwa and Dar es Salaam. Even

\footnotetext{
42 As Frere reported: 'The Banians generally keep to the forts, or within a short journey of the Coast or navigable parts of large rivers. The trade with the far interior is almost exclusively in the hands of Arabs, or Arab half-castes, and Swahili'. F.O. 84/1391] Frere to Granville, 7 May 1873,

${ }^{43}$ John Gray, Tanganyika Notes and Records, no. 19 49, 240. By 1857 Musa Msuri had settled in Tabora where, according to Burton: 'He had become at the age of forty-five or so the pre-eminent man of business $[\ldots]$ large investments of wire, beads, and cotton cloths, some of them valuable, are regularly forwarded to him from the coast [....] His gains [...] are principally represented by outlying debts: he could not leave the country without enormous sacrifices'. Burton, Lake Regions, London 1869 [Vol 1] p 323, [Vol 2] 223-226.
} 
then, very few Hindus settled before 1900 [See table 1 below]. They were hardly known to travel into the interior until the Uganda Railway was build.

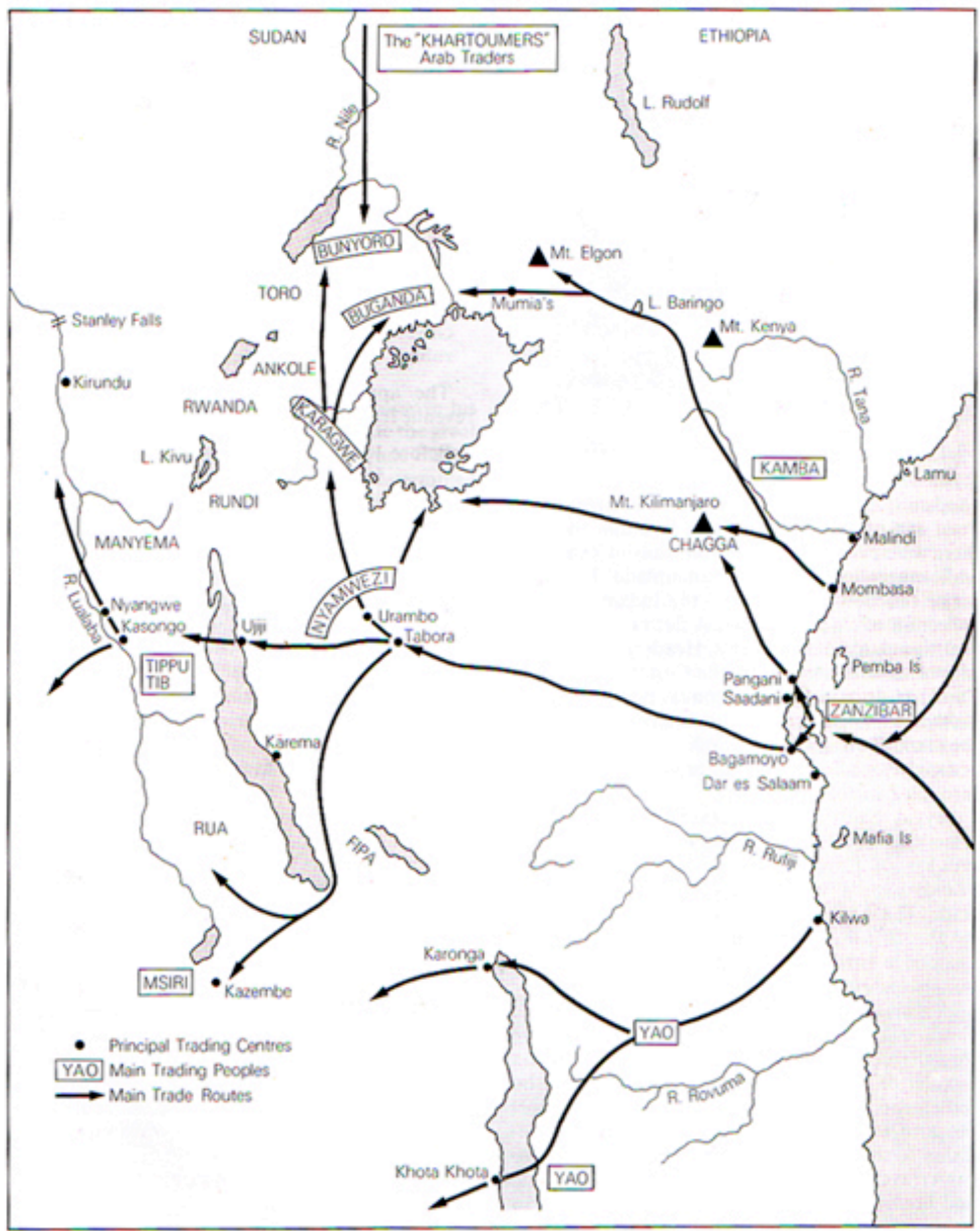
Eddingburgh, Longman 1977, page 92. 


\begin{tabular}{|c|r|r|r|r|r|r|r|r|r|r|r|}
\hline & \multicolumn{3}{|c|}{1870} & \multicolumn{4}{|c|}{1887} & \multicolumn{4}{|c|}{1901} \\
\hline Town & Muslim & Hindu & Total & Muslim & Hindu & Other & Total & Muslim & Hindu & Other & Total \\
\hline $\begin{array}{c}\text { Bagamoyo/ } \\
\text { Saadani }\end{array}$ & 137 & 54 & 191 & 592 & 31 & & 623 & 929 & 25 & 5 & 959 \\
\hline $\begin{array}{c}\text { Dar es } \\
\text { Salaam }\end{array}$ & 53 & 52 & 105 & 92 & 15 & & 107 & 631 & 301 & 132 & 1064 \\
\hline $\begin{array}{c}\text { Kilwa (\& } \\
\text { Mungano) }\end{array}$ & 197 & 33 & 230 & 212 & 40 & & 252 & 293 & 71 & 14 & 373 \\
\hline $\begin{array}{c}\text { Lindi/ } \\
\text { Mikindani }\end{array}$ & 142 & 30 & 172 & & & & & & & & \\
\hline Mombasa & 1402 & 90 & & 292 & 218 & 117 & 9 & 344 \\
\hline Zanzibar & 2350 & 200 & 2550 & 2389 & 618 & 79 & 3086 & & & & \\
\hline TOTALS & $\mathbf{2 ~ 8 7 9}$ & $\mathbf{3 6 9}$ & $\mathbf{3 2 4 8}$ & $\mathbf{3 4 8 7}$ & $\mathbf{7 9 4}$ & $\mathbf{7 9}$ & $\mathbf{4 3 6 0}$ & $\mathbf{2 ~ \mathbf { 0 7 1 }}$ & $\mathbf{5 1 4}$ & $\mathbf{1 6 0}$ & $\mathbf{2 7 4 0}$ \\
\hline
\end{tabular}

Table-1: Number of Hindus and Indian Muslims per Town and Year

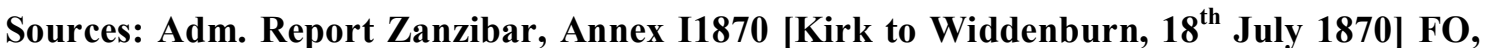
confidential print 44/1936, pp. 22-23; Census of British Indian subjects in the Dominions of the Sultan of Zanzibar, [Major McDonald to Foreign Office] FO 19 December 1887, FO 84/1854; Annual Report, 1901-02, GCA Annual Report.

For example, the first Hindus known in Nairobi came after the railway arrived at Nairobi in the 1900s. ${ }^{44}$ One of my elderly informants, Sunderjibhai [99 years in 2003], remembers his father and grandfather faced difficulties in opening new business ventures upcountry because of 'food problems'. They even decided to close their business in Jinja because the food was cooked by 'outsiders' since there were no Hindu women or Brahmins there.

I remember that my father told me about his uncle who opened branches of our company in Mombassa and Jinja in 1905. At that time Jinja must have been a very small place. And he placed a manager there. However, in Jinja there were no Hindu families as such. The foods were cooked by the local people and being vaisnavanias they find it very difficult to stay. They eventually had to close the Jinja branch, because of the food problems, because the managers would not accept the food prepared by the locals. Because they were strict vegetarians. But in Nairobi and Mombassa and even in Zanzibar there were no problems at that time. ${ }^{45}$

It is difficult to find out whether the importance of food was the only reason to close down the Jinja business. However, at that time other Indian communities were rising and the town was 'flourishing'. ${ }^{46}$ Members of other communities who had family

\footnotetext{
${ }^{44}$ Salvadori, Through Open Doors, 97, 99, 106.

${ }^{45}$ Interview, Sunderjibhai 10 oct 2000.

${ }^{46}$ TA (Tanganyika Archives) G-21, 6.
} 
members in that area supported the fact that Jinja was developing in the early twentieth century. It is, however, plausible that the food habits of Hindu Lohanas hampered their economic development in this area. When asked to compare his father's and grandfather's food habits, Sunderjibhai suggested that there was only a slight change between the two.

There was not much change in the eating habits as far as my father is concerned. The only thing I heard from my father is that my grandfather was a man of taste, he was strict to certain items in the food whereas my father followed the same style, but this was more 'free style' than my grandfather. But they were all vegetarians. My father didn't mind going around. Although he was a vaisnavias, he didn't mind eating out. So, he was not as strict as his father. ${ }^{47}$

The father and the grandfather remained strict vegetarians and would not drink alcohol. Nevertheless 'eating outside' slowly became acceptable, which was a necessary condition for expanding business overseas and upcountry. Salvadori mentions a small group of Brahmins who settled in Nairobi, running small restaurants. This may have paved the way for other Hindus to settle there. ${ }^{48}$ Sunderjibhai and other informants did not remember any of the hostile encounters with Muslims that Sayyida Salme recalled for Zanzibar. According to him the number of Asian Muslims and Arabs were too small upcountry to make 'a big deal of the religious differences'. However, he admitted that Hindus would 'stick to themselves' wherever possible, 'to avoid unnecessary inconveniences'. It is very difficult to make something out of these vague statements, but it seems plausible that they mainly refer to the Hindu notions of purity and impurity.

Nevertheless, this notion of the 'purity of food' changed in the following generations. Some members of the second generation of Hindu Lohanas started to eat meat and/or drink alcohol. ${ }^{49}$ In most of these instances, however, it was not the first or second son

\footnotetext{
${ }^{47}$ Sunderjibhai 10 oct 2000

48 Salvadori, Through Open Doors, 97, 99, 106. The food restrictions are not so strong observed in East Africa as in India but, even so, it is Brahmins who operate the many vegetarian restaurants and sweet shops. In the second and third generation it has become fashionable to have a Brahmin cook in the house. See G. Oonk, 'The changing culture of the Hindu Lohana community in East Africa', Contemporary South Asia 13 (1) 2004, 7-23.

49 Out of seven 'first generation' informants, only one ate non-vegetarian food and drank alcohol. Two had drunk alcohol for some years but quit a few years back. In this generation I gathered information on only three women. Two of them were non-drinkers and vegetarians. One drank regular at dinner parties and ate meat. All my informants were male. Based on twelve informants, I gathered information on the
} 
who altered eating and drinking habits in the family, but rather the third or fourth (or next) son only who did so. Confronted with this observation, most second-generation informants admitted that it would be more difficult for the first and second son in the family to become a non-vegetarian than for the others. This often was a two-way affair. The eldest son could not break the tradition 'out of respect' for his father, whereas for first-generation informants it was important that at least the first two or three sons kept their traditions. This, however is not unusual in inter-generational change, irrespective of culture or country. The first child has to struggle to get their own voice and to do things differently. The point is that here the intergenerational change focuses on 'Hindu purity'.

Most second-generation informants who started to drink alcohol and/or eat nonvegetarian food remember the first time they did so very well. It was as if they felt their father watching their change of life-style. They felt ashamed and avoided discussing this with their parents, mainly out of respect. It was always in their teens or early twenties, and always together with Europeans (not with Africans). Anyu, who is now in his early seventies, recalls:

My father had sent me to a missionary school in Pune, India. The majority of the students there were British. They used to drink beer outside the campus and I felt that I wanted to be a part of that group. After I tasted my first beer, I knew I would continue drinking. Moreover, in our family drinking liquor was associated with diseases, being drunk and dirty and all that. This was not what I encountered with the European students. They were quite decent. However, when I started studying in the UK in the sixties, I saw some students getting drunk all weekend. I didn't like it. ${ }^{50}$

The second-generation informants had their first taste of beer or alcohol outside their parents' house. ${ }^{51}$ Often they were among Europeans with whom they studied in India,

food habits of thirty-two people. Fourteen were regular drinkers, whereas 19 eat meat more than once a week.

${ }^{50}$ Interview Anyu Bengal, June 1999. These statements are often full of contradictions, because shame would suggest they would not do it again. Rather, it is the struggle between different forms of learned behaviours and socialisations that lead to struggles, again irrespective of whether you are a migrant or not.

${ }^{51}$ Some notes on the use of 'generation'. With the first generation I mean migrants who migrated between 1880 and 1920 and who decided to stay in East Africa. The second generation was raised in East Africa (but may be born in India), somewhere between 1920-1960 and the third generation was born and raised in east Africa after the 1960s. 
East Africa or the United Kingdom. In many cases informants felt 'confronted' with the 'natural' way that drinks were served and accepted. They slowly started to share the fact that they drank alcohol with other Indian friends. But they wouldn't share this with their parents.

Eating meat or drinking alcohol was never done in the house of the parents. Even in restaurants, or at dinner parties and marriages, no one would drink in front of his father. Here the word 'respect' occurs. 'I would never drink in front of my father,' Anyu states, 'out of respect'. Curiously, the mother was hardly mentioned when we discussed this. At the same time informants were pretty sure that their father knew that they had changed their food and drinking habits. Anyu recalls: 'I never drank in front of my father or my uncle. Out of respect: I think that he suspects, but it is such a thing, which you don't like to discuss. But of course they suspect. But they don't want to admit for themselves. But they knew. 52

And they knew indeed. In two cases second-generation informants handed over the will of their father. Both of these were addressed to the eldest son, written in Gujurati. One of them stated: 'Please encourage your younger brothers to behave properly in the tradition of the community. Ask them to refrain from unhealthy habits.' Anyu admitted that the 'unhealthy habits', included his smoking and drinking habits.

In another example a will stated: 'It is my request to renounce all addictive habits [in this example, smoking and drinking, G.O] and to act in accordance with the council and feeling of Motobhai [elder brother, G.O] and the Kakas [uncles, brothers of the deceased, G.O.] ${ }^{53}$ These wills and the statements of the informants reflect the silencing of the subject. It was not something you openly discussed with your father. But at the same time its mention in the wills shows how important it was.

Sometimes the differences in food habits within the family were used purposely. For example, take the case of two brothers running their father's family business. One is living in Mombasa with his father, who is more or less retired. In this house they are strictly vegetarian and no alcohol is served. The second brother lives in Dar es Salaam

\footnotetext{
${ }^{52}$ Interview Anyu Bengal, June 1999.

${ }^{53}$ Will of A.A. Chande, 1959. Copy of translation with the author.
} 
where he runs a trading business. He told me that, after World War II, there was an unspoken agreement that whenever they had to 'entertain business relations' who were known as 'drinkers', mostly Europeans, they would do that in his house, and whenever they entertained strict vegetarians they were invited to the Mombasa house. The brothers accepted their different food habits, whereas the father just didn't talk about this matter.

Nowadays, in this family, eating meat or not and drinking beer or not is not an issue. It is something you do, or you don't. It is not discussed. It is known and accepted. Nevertheless, in Nairobi I came across a group of 'second generation' businessmen who tried to legitimise their habit of eating red meat, especially beef. They all started to eat beef about ten years ago when 'it became acceptable'. I asked them whether the cow was not 'holy' anymore in their community. To my surprise they replied that it was but that African cows were not holy in their view, only cows in India were. A local Brahmin of the Hindu Lohana Temple told me that this justification was not acceptable in his community. Therefore they invited Brahmins from India to pledge vegetarianism in their community.

Some of the lectures in the Hindu Lohana temple in Dar es Salaam were related to the subject of food. Religious traditions and reasons of health were the main arguments to convince the audience to eat vegetarian food only, with some success. One of my thirdgeneration informants recalls how her father, who used to eat meat and drink, had become vegetarian again:

My father used to eat meat and drink, but he stopped two years ago. I am allowed to eat chicken. It is not a big deal. But we don't eat it in the house. He stopped because of this man, you know from India, who comes to the temple and gives a lecture. Basically what happened is that this man said that when you eat meat, you make a graveyard of your stomach... My father was touched by that. ${ }^{54}$

This example shows that being vegetarian and not drinking alcohol is an important part of Hindu tradition. Nevertheless, it also becomes a part of an individual's choice. The father did not force his children to become vegetarian again. Nowadays we come across

\footnotetext{
${ }^{54}$ Interview Raksha Bihari, December 2002. In addition I came across several men in their sixties who had a background of eating meat and drinking alcohol but who decided to become vegetarians again and dress in a more 'Indian style' after retirement.
} 
families (sometimes even nuclear families, as in this case) where we see that some members are vegetarian-non-drinkers whereas others are non-vegetarian drinkers. People know which family members are vegetarians and which not. It has become generally accepted and respected and it is hardly discussed among and between families.

The old traditions of 'cleanliness' and 'being pure' are reproduced here in a different way. Nowadays it is known in which house vegetarian food only and/or no alcohol is served. In the above example, the father decided to become vegetarian again. The mother never doubted her faith and never ate meat. So it was the male family member who decided whether 'meat was tolerable' in the house. His children are allowed to eat non-vegetarian, but not at home. It is accepted for other family members and friends that in this house there is no meat nor alcohol. In houses where meat and alcohol is accepted, families will always make sure that vegetarian dishes are readily available during dinner parties and other occasions.

In general eating non-vegetarian and drinking alcohol has become acceptable in the Hindu community and is not widely discussed. People do know who is strict vegetarian and who isn't. The tradition of 'purity and impurity' is important in the close circles of the temple and the temple organisation. For many of the elite business families the circles around other big businessmen, ex-pats and European business partners have become more important. It is in these circles that the habits of drinking alcohol and eating meat continue.

In the second generation two more changes related to marriages occurred. First, there was the development of a preference for a Hindu woman raised in East Africa, instead of a Lohana woman raised in India. However, the demand for (Lohana) Hindu women from India was still strong due to the fact that there were twice as many Hindu men in East Africa as Hindu women. ${ }^{55}$ Second, a loosening of caste boundaries occurred when

\footnotetext{
55 The Tanganyika Census of 1931 counted 5,162 Hindu men and 2,600 Hindu women, Report on the Non-native Census, 26 April 1931, p. 38. Note that the issue here is not where the woman was born. In many cases she might be born in India, as it was the practice for Hindu women to have their babies at their mothers' place whenever possible. Often this was in Gujurat, India. After delivery mother and child would go back to East Africa where the child was raised.
} 
it came to finding partners. These developments show that East Africa had become a home for Hindu Lohanas.

Anyu is a typical example of a Hindu Lohana who did not marry within the Lohana community. He fell in love with a Patel woman and proposed to her. He is the first male member in his family to break the Lohana chain. Two of his elder sisters had already married outside the community, and that they married within the Hindu community was considered 'good enough'. This again underlines the strength of the patriarchal structure of the Hindu Lohana community but also that the demand for 'local raised women' was high. Nevertheless, it was not an easy task for a young man to convince his father that he wanted to marry outside the caste.

It took me a year to convince my father. Though, I have to admit that he was pretty cool about it. In the sense that, of course he did tell me that and advised me that I was the first one of the male heritage of my family to be breaking this particular tradition. I said, but to me an Indian is an Indian. I must say, there was some resistance more from some of my brothers. They are more traditional I would say. My father was pretty open-minded to this, once you talked with him, even to the extent of accepting marrying a non-Indian or a Muslim person. My youngest brother is married to a Muslim person. So he accepted this. ${ }^{56}$

What was the argument that convinced him?

Well basically, I said, 'Give me one reason, besides the argument that I am breaking any particular traditional pattern, that I should not marry this woman.' If I was to marry someone from a different religion, then I can understand. But there is no change in the religion, there is no change in the tradition even. We both speak Gujurati. I can understand, I can accept his argument, if it was a different religion, different race, then fine, then you have to think about what happens to the offspring. But he was not able to give such an argument. I think finally he saw my point of view without admitting it. But we had various discussions about this thing. 57

In spite of his reasoning, something did happen to his offspring. His two daughters do not consider themselves Lohanas (born out of a Patel), but Hindus. In their families the specific caste term 'Lohana' will lose its meaning. Nevertheless, this is not considered

\footnotetext{
${ }^{56}$ Interview Anyu Bengal, June 1999

${ }^{57}$ Interview Anyu Bengal, June 1999. Please recognize that changing food habits were not discussed with the father, whereas with choosing a marriage partner it could not be avoided.
} 
to be a problem by either the parents or the children. At the same time, the perception of the elder brothers of Anyu didn't change. Some of them still want to see their own children marrying within the same caste. Anyu observed, 'However, I don't think their children will raise the same resistance as I had. So if they show up with another Hindu, this would be acceptable.'

In another case it was not the male Hindu Lohana member who married outside the community, but the female. In the last few years, the marriages of Hindu Lohana woman outside their Lohana community have raised some debates in the community. In contrast with the male members, females are not considered Lohanas any more if they marry outside the community. People around the Hindu Lohana Temple executive committee told me that after heated discussion, the question of whether these women members should be allowed in various temple ceremonies came down to one vote. It was the Brahmin priest who convinced several community members. The irony of the case was that the daughter of one of the main members of the committee had married outside the community, and despite organising various special celebrations with the other women and her mother, she was not allowed to attend these anymore. ${ }^{58}$

Despite the constraints for female Lohanas described above, the male members developed a preference for an East Africa-born Hindu spouse, even when this sometimes meant marrying outside their own caste. The main reason for this was that they knew 'East African culture'. This included all kinds of general attitudes, like the 'slow pace of life', knowledge of Swahili and how to train African servants, and how to cook local Gujurati food, which by then had already changed in East Africa. It was less spicy, more mild, sometimes with coconut milk and the use of ghee was declining. ${ }^{59}$ In this second generation it became acceptable for an African servant to cook the food. This would have been unthinkable in the first generation. Nevertheless many Lohana families emphasise that their wives supervise the process of cooking and in other examples they are very proud to employ a Gujurati cook from India.

\footnotetext{
${ }^{58}$ Interview with Bihari Bengal, January 2003

59 There is an interesting paragraph on the Swahili and Oriental influences of Indian/Gujurati cuisine in East Africa in A. Y. Lodhi, Oriental Influences in Swahili. A Study in Language and Cultural Contacts, Göteborg 2000, pp. 83-89.
} 


\section{Conclusion}

In the anthropological and historical discourse, hybridity and cultural change of religion are often associated with ideas of syncretism. Here hybridity refers to the cultural processes which fuse together two distinct religious orders. The classical cases include the incorporation of Christianity into indigenous religions. Hybridity, then, is the space that occurs betwixt and between two other authentic zones. It is seen as comprising a mixture of opposites, but it does not necessarily signify a disruption of the prior purity or authenticity of these polarities. ${ }^{60}$ In analysing the process of cultural change "from below', in a non-western context, we may make three observations here.

(1) In our case the process of 'cultural adaptation' started before migration actually happened. Contacts between Hindus and the East-African coast have a long history. However, Hindus settled relatively late in Zanzibar and along the East African coast. This was mainly due to various constraints within the Hindu community related to the notion of 'purity'. The first constraint was the taboo on travel overseas. Some suggestion is made that the taboo itself was not in full force, but the fact that women and children remained in the homeland, may well have represented a kind of substitution, in order to keep the family 'pure'. The fact that the woman of the household did not travel beyond the seas seems to have been sufficient to ensure the continuing purity of the household. This caused different inconveniences, especially related to the notion of food. As Hindu men were only allowed to accept food cooked by Brahmins or from caste fellows, it was very inconvenient to explore areas where there was no Hindu community. This was true for Zanzibar and the East African coast and partly accounts for their relatively late entry in the East African interior.

Despite this, a growing the Hindu community settled in Zanzibar and along the East African coast, invited, after 1832, by Arab rulers who encouraged them to move from Muscat to Zanzibar. Among other things, the Sultan of Oman made the Hindu Bhatia, Jairam Sewji the custom master of Zanzibar. And in his turn, Sewji invited his caste members to take part in the economic opportunities in that part of the world. In addition, Sultan Seyyid Bargash made several provisions for Hindu women to settle in Zanzibar in the 1880s. All these must have encouraged some Hindus families to do so, as there

\footnotetext{
${ }^{60}$ N. Papastergiadas, The Turbulence of Migration, Globalisation, Deterritorialization and Hybridity,
} Polity Press, Cambridge 2000, 208-209. 
was a steady increase of Hindus on the island. Nevertheless, the favourable attitude of the Arab elite contrasted strongly with the hostile feelings Hindus encountered from low class Arabs and many local Swahili. These hostile feelings may well be a reaction to the fact that many Indians were moneylenders who had advanced money on landed securities to Swahili and Arabs who may have lost a part of their possessions to Hindus. Because of their dress habits and their physical appearance they were easy targets, especially in periods of economic decline. The outcome was that Hindus tended to settle more and more on the East African coast and they were inclined to settle amongst each other, in the same neighbourhoods, the same areas in cities.

(2) In our case there was no merger of religions but a merger of 'castes' within a religion. There was an increasing demand for Hindu wives who were raised in East Africa. Frequently, Hindu men sidestepped the tradition of marrying within the caste/community. This was not only due to a shortage of women within the community, but also to the growing preference for marrying someone who 'knew the African way'. By this Hindu men meant the changing food habits, the understanding of how to train African house girls and the differences in culture with India. Despite this, the wife had to be a Hindu. Marriages with Indian Muslims, Africans and Europeans are still very uncommon. Though the middle classes in India may have experienced similar developments, the Hindus in East Africa agree that this was not to the same extent as in East Africa.

In the second generation the notion of Hindu 'purity' eroded further. In the case of the acceptance of drinking alcohol, and to a lesser extent eating non-vegetarian food, the exposure to European culture seems to have been of prime importance. Once drinking and eating meat were accepted, they became instrumental in the entertainment of business relations. In this sense it broadened the social circles of Hindus. The same came about with the choice of spouses. The loosening of caste and community ties within East Africa enlarged social relations with other Indian groups. At the same time India faded as a marriage market.

(3) The direction of change and adaptation of food habits aims were responses to the economically dominant European culture and not to the numerically dominant African culture. The settlement of a fairly large Hindu community of around 6,000 in East 
Africa in 1900 paved the way for new developments within the community. First, there was a growing acceptance of non-vegetarian food and alcohol in the Lohana business community. Most Lohana men admitted that they started drinking while they studied with Europeans. Exposure to the European acceptance of alcohol made them change their own ways. Nevertheless most felt it was an individual decision, and they were not emotionally forced to do so. Once drinking had become accepted in certain families it was used in their strategy to entertain business relations. The notion of 'purity' developed into something which was related to the house, and to a lesser extent to the individual. In some houses, drinking alcohol and/or eating meat was accepted, whereas in other houses it wasn't.

Though it would be difficult to prove the validity of all such traits, they remain common stereotypes that determine much in the way of attitudes and social formations. This article has described the process of cultural adaptation in a non-western context. By taking a perspective 'from below', the research reveals that cultural change is often an obscure and subtle process, whose direction is seldom clear. Notions of desirable directions are confronted with undesirable outcomes. An empirical historical approach leaving room for change over time, paradoxes and differences- gives meaning to popular -but often empty- terms like 'globalisation', 'westernisation' and 'creolisation'.

\section{Bibliography}

Burton, Richard F. (1987 [1856]) First Footsteps in East Africa or, An Exploration of Harar, New York: Dover Publications.

Burton, Richard F. (2003 [1872]) Zanzibar, Elibron Classics.

Burton, Richard F. (1869) Lake Region, London.

Chaudhuri, K.N. (1985) Trade and Civilization in the Indian Ocean. An Economic History from the Rise of Islam to 1750, Cambridge: Cambridge University Press.

Chaudhuri, K.N. (1990) Asia Before Europe. Economy and Civilisation of the Indian Ocean from the Rise of Islam to 1750, Cambridge: Cambridge University Press.

Christie, James (1876) Cholera Epidemics in East Africa. An account of the several diffusions of the disease in that country from 1821 till 1872, with an outline of the geography, ethnology, and trade connections of the regions through which the epidemics passed, London: Macmillan.

Clarence-Smith, W.G. (2001) "Indian and Arab Entrepreneurs in Eastern Africa, 18001914" in H. Bonin and M. Cahen (eds.) Négoce blanc en Afrique Noire: 
L'évolution du commerce à longue distance en Afrique Noire, du $18^{e}$ au $20^{e}$ siècles, Paris: Société Française.

Cohen, R. (1997) Global Diaspora. An Introduction, London: Routledge.

Drummond, D. (1980) “The Cultural Continuum: A theory of Intersystems," Man, 15: 352-374.

Gregory, R.G. (1993) South Asians and East Africa: An Economic and Social History 1890 - 1980, Boulder Colorado: Westview Press.

Guha, R. (1996) Dominance without Hegemony, Cambridge: Harvard University Press.

Hannerz, U. (1996) 'The World in Creolisation', Africa 57(4): 546-559.

Herskovits, M.J. (1938) Acculturation. The Study of Cultural Contact, New York: J.J. Augustin.

Keesing, R.M. (1976) Cultural Anthropology: A Contemporary Perspective, Canberra: CBS College Publishing.

Lewis, B. (1997) “The West and the Middle East (history of relations)", Foreign Affairs January: 1-21.

Lodhi, A.Y. (2000) Oriental Influences in Swahili. A Study in Language and Cultural Contacts, Göteborg: Acta Universitatis Gothoburgensis.

Mamdani, M. (1973) From Citizen to Refugee: Uganda Asians Come to Britain, London: Frances Pinter.

Markovits, C. (2000) The Global World of Indian Merchants1750-1947. Traders of Sind from Bukhara to Panama, London: Cambridge University Press.

Mehta, M. (2001) "Gujarati Business Communities in East African Diaspora. Major Historical Trends," Economic and Political Weekly, 19 May 2001: 1738-1747.

Nagar, R. (1996) "The South Asian Diaspora in Tanzania. A History Retold," Comparative Studies of South Asia and the Middle East, 16(2): 62-80.

Nandy, A. (1983) The Intimate Enemy, Delhi: Oxford University Press.

Naseem, Abdul Waheed (1975) Nature and the Extent of the Indian Enterprise Along the East African Coast And Subsequently in the Development of Kenya 18401905, Ph.D. thesis, St. John's University, New York.

Oonk, G. (2004) "The Changing Culture of the Hindu Lohana Community," Contemporary South Asia 13:(1): 7-23.

Oonk, G. (2004) “"After shaking his hand, start counting your fingers”. Trust and Images in Indian Business Networks, East Africa 1900-2000', Itinerario 18:(3): 70-88.

Oonk, G. (2006) 'South Asians in East Africa (1880-1920) with a particular focus on Zanzibar: Toward a Historical Explanation of Economic Success of a Middlemen Minority', African and Asian Studies 5(1): 57-89.

Oonk, G. (2008) "“We lost our gift of expression". Loss of the mother tongue among Indians in East Africa, 1880-2000', in G. Oonk (ed.), Global Indian Diasporas: Exploring Trajectories of Migration and Theory, Amsterdam: Amsterdam University Press.

Palgrave, W.G. (1865) Narrative of a year's Journey through Central and Eastern Arabia, London. 
Papastergiadas, N. (2000) The Turbulence of Migration, Globalisation, Deterritorialization and Hybridity, Cambridge: Polity Press.

Pearce, F.B. (1967 [1920]) Zanzibar: Zanzibar. The Island Metropolis of Eastern Africa, London: Frank Cass \& Co.

Pearson, M.N. (1998) Port Cities and Intruders. The Swahili Coast, India, Portugal in the Early Modern Era, Baltimore and London.

Ramchandani, R.R. (1976) Uganda Asians. The End of an Enterprise: A Study of the Role of the People of Indian Origin in the Economic Development of Uganda and their Expulsion, 1894-1972, Bombay: United Asia Publications.

Redfield, R., Linton, R. and Herskovits, M. (1935/36) 'Outline for the study of acculturation,' American Anthropologist 38: 149-152.

Ruette, Emile (ed.) (1998 [1886]) Princess Salme of Zanzibar and Oman, Memoires of an Arabian Princess, (Zanzibar: Gallery Publications.

Salvadori, C. (1983) Through Open Doors. A view of Asian Cultures in Kenya, Nairobi: Kenya Publications.

Salvadori, C. (1997) Two Indian Travellers: East Africa 1902-1905, Mombasa: Friends of Fort Jesus.

Sheriff, A. (1971) The Rise of a Commercial Empire: An Aspect of the Economic History of Zanzibar, 1770-1873, Ph.D. thesis, University of London.

Vertovec, S. (2000) The Hindu Diaspora. Comparative Patterns, London: Routledge.

Voigt-Graf, C. (1998) Asian Communities in Tanzania, Hamburg: Institut für Afrikakunde. 